\title{
Overcharge Protection for Rechargeable Lithium Batteries Using Electroactive Polymers
}

\author{
Guoying Chen* and Thomas J. Richardson**,z \\ Environmental Energy Technologies Division, Lawrence Berkeley National Laboratory, Berkeley, \\ California 94720, USA
}

A conducting polymer shunt capable of providing overcharge protection for rechargeable lithium batteries via a reversible, internal, self-actuating mechanism is described. A microporous separator was impregnated with poly(3-butylthiophene), an electrochemically active polymer that becomes electronically conducting when oxidized. The morphology of the resulting composite membrane and its electrochemistry in a lithium battery electrolyte were examined. The composite membrane was introduced into a $\mathrm{TiS}_{2}$ - Li cell as an overcharge protection separator. While the discharge capacity of an unprotected cell was rapidly degraded when it was charged above $4 \mathrm{~V}$, the protected cell was undamaged by overcharging by as much as ten times the normal capacity. The excess charge current was carried by the polymer, which limited the charging potential to about $3.2 \mathrm{~V}$. (C) 2003 The Electrochemical Society. [DOI: 10.1149/1.1633162] All rights reserved.

Manuscript submitted April 16, 2003; revised manuscript received July 30, 2003. Available electronically December 3, 2003.

Overcharging of lithium batteries leads to irreversible damage to cell components and may cause serious safety problems. ${ }^{1}$ Overcharging of one or more cells within a high voltage multicell stack of the type required for vehicle traction can render the entire stack inoperative. External protection mechanisms that interrupt the charging process when a voltage, temperature, or internal pressure limit is reached are currently in use in consumer electronics battery packs, but these add weight, volume, and cost and may not allow the continued operation of a cell stack. Redox shuttle additives can provide an internal, automatic overcharge protection mechanism that allows charging current to pass through a cell without overcharging it. $^{2-5}$ However, their ability to carry useful overcharge currents is limited by their low diffusion coefficients relative to that of lithium ion. Polymerization (or shutdown) additives, which make cells resistive by forming insulating polymers upon overcharging or actuate pressure disconnects by generating gases, are attractive only for small batteries where it is practical to remove a damaged cell from operation and replace it. Denton et al. ${ }^{6}$ have described the use of electroactive polymers in various configurations to provide overcharge and overdischarge protection for lithium batteries.

Generally, electronically conductive polymers are synthesized by oxidative polymerization, either chemically or electrochemically. The latter route typically produces oxidized (p-doped) polymers with high porosity and good internal chain connectivity. However, the morphology of electropolymerized deposits is dendritic and difficult to control. Chemically prepared polymers have more uniform (but smaller) molecular weights and better solubility. A wide range of conductive polymers is commercially available in either neutral (insulating) or conducting forms. The poly(3-alkyl or 3 -arylthiophenes) are soluble in common organic solvents, and their electrical, mechanical, optical, and thermal properties depend on the identity of the substituents on the thiophene rings. ${ }^{7}$ Poly(3butylthiophene) (P3BT) was selected for this study because of its relatively high oxidation potential and its stability at potentials near that of lithium metal. In a detailed investigation of the optical and electronic properties of this polymer that will be reported elsewhere, it was found that its electronic conductivity varied by eight orders of magnitude from $10^{-9} \mathrm{~S} / \mathrm{cm}$ in the neutral state to $0.1 \mathrm{~S} / \mathrm{cm}$ at the maximum stable doping level of about 0.28 electrons per formula unit. These values are similar to those reported for poly(3-methylthiophene). ${ }^{8}$ Sustained current densities as high as $300 \mathrm{~mA} / \mathrm{cm}^{2}$ in oxidized polymer films were achieved at applied potentials of less than $4.2 \mathrm{~V}$. Thus, it should be possible to provide overcharge protection through a conducting polymer short compris-

\footnotetext{
* Electrochemical Society Student Member.

** Electrochemical Society Active Member.

${ }^{\text {z }}$ E-mail: tjrichardson@lbl.goy
}

ing only a few percent of the separator area. Here we show that a self-actuating, reversible conducting polymer shunt may be capable of providing high current overcharge protection.

\section{Experimental}

Neutral P3BT (Aldrich) was dissolved in chloroform containing 5 vol \% of dimethylformamide (DMF), with brief ultrasonic treatment to speed dissolution, giving a homogeneous $0.02 \mathrm{M}$ solution. $2.8 \mathrm{~cm}^{2}$ disks cut from a commercial $25 \mu \mathrm{m}$ polypropylene battery separator membrane (Celgard 2500) were impregnated with the polymer by applying a uniform coating of the polymer solution on one side, allowing the solution to thoroughly dry, and then repeating the process for the other side of the membrane. The resulting composite membrane was $27 \mu \mathrm{m}$ thick and contained $0.4 \mathrm{mg}$ of P3BT. For electrochemical characterization, the polymer was cast onto a 200 mesh, $2.6 \mathrm{~cm}^{2}$ stainless steel electrode. $\mathrm{TiS}_{2}$ electrodes were prepared by casting slurry containing $80 \mathrm{wt} \% \mathrm{TiS}_{2}$ powder, $10 \mathrm{wt}$ $\%$ carbon black, and $10 \mathrm{wt} \%$ poly(vinylidene difluoride) in $n$-methylpyrrolidinone onto a graphite fiber mat (Lydall Technical, Technimat $6100-035)$. After drying at $75^{\circ} \mathrm{C}, 1.6 \mathrm{~cm}^{2}$ cathode disks were punched from the mat and Swagelok-type cells with $\mathrm{TiS}_{2}$ composite cathodes, $\mathrm{Li}$ foil anodes, and stainless steel current collectors were assembled in an inert atmosphere glove box with oxygen con-

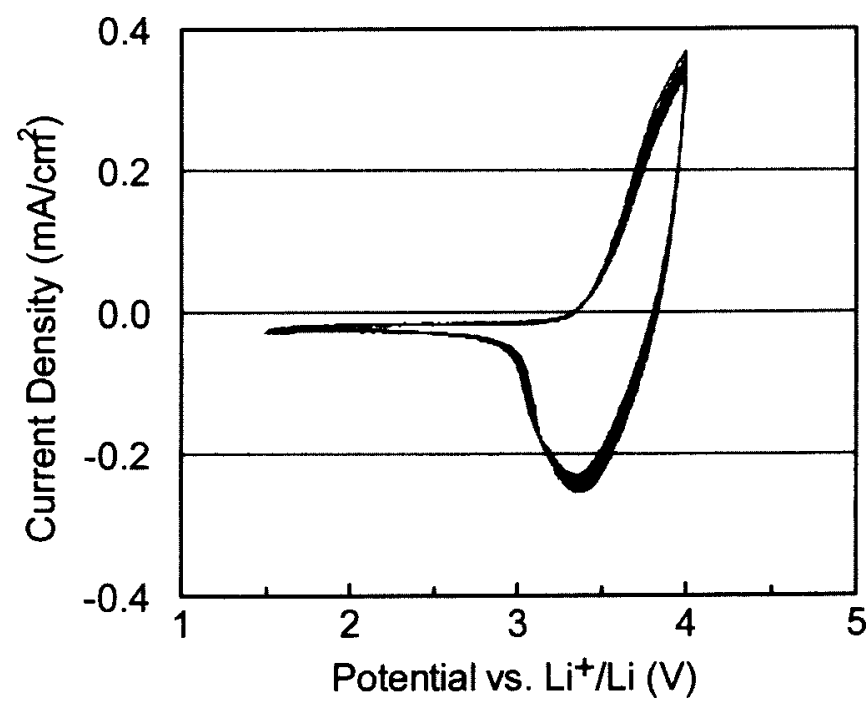

Figure 1. $\mathrm{CV}$ of $\mathrm{P} 3 \mathrm{BT}$ in $1.0 \mathrm{M} \mathrm{LiPF}_{6}$ in $1: 1 \mathrm{EC}: \mathrm{PC}$ (sweep rate $5 \mathrm{mV} / \mathrm{s}$, Li foil counter and reference electrodes). 


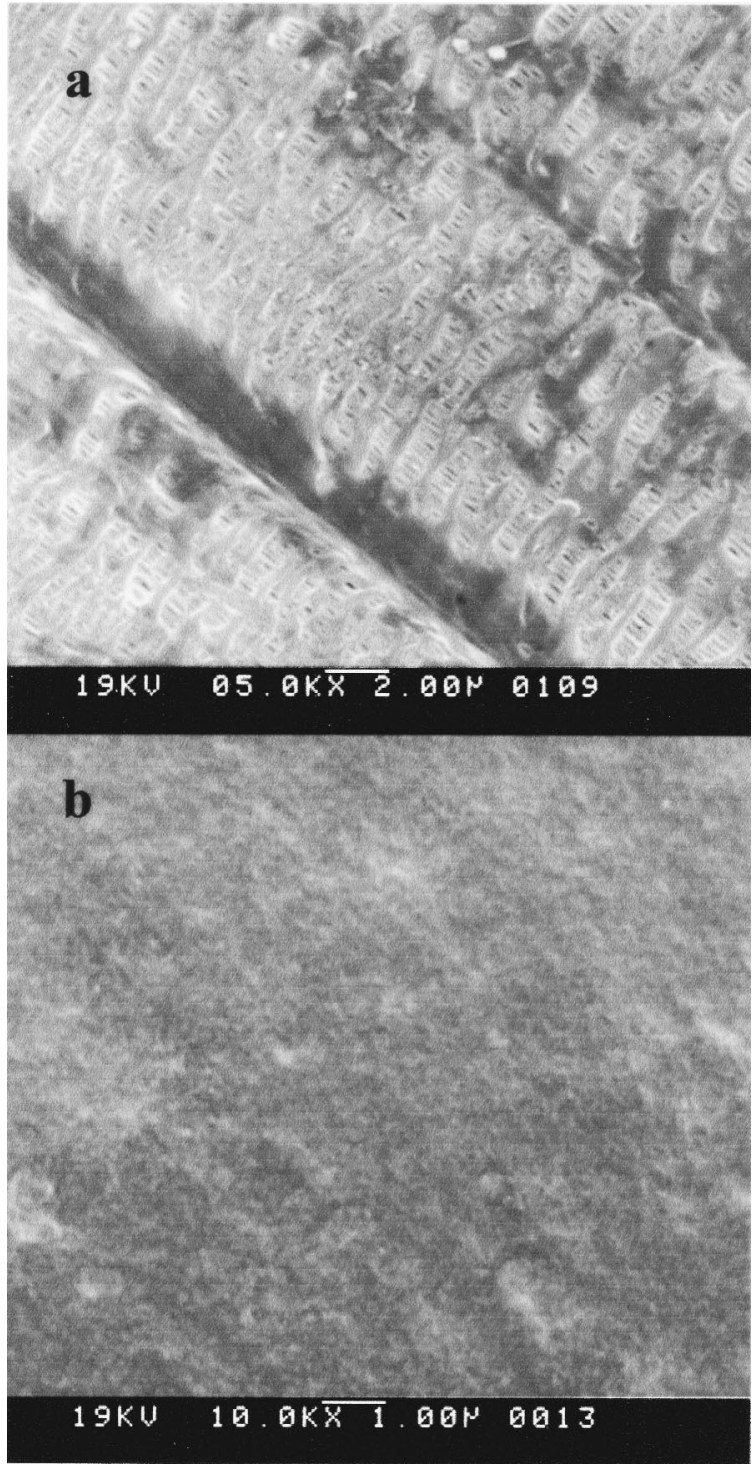

Figure 2. Scanning electron micrographs of separator (a) before and (b) after P3BT deposition.

tent $<1 \mathrm{ppm}$ and water $<5 \mathrm{ppm}$. The electrolyte was $1.0 \mathrm{M} \mathrm{LiPF}_{6}$ in a 1:1 mixture of propylene carbonate (PC) and ethylene carbonate (EC), (Ferro Corporation). Unprotected $\mathrm{TiS}_{2}-\mathrm{Li}$ cells used plain polypropylene separators, while the overcharge-protected cells had separators impregnated with P3BT as described above. In both cases, a slight axial pressure was applied to the cells by an internal, stainless steel spring. Cyclic voltammetry (CV) studies and constant current charge-discharge cycling experiments were carried out at room temperature inside the glove box, using an Arbin multichannel battery testing system.

\section{Results and Discussion}

Characterization of P3BT and composite separator membranes.-Ten CV cycles for P3BT cast onto a mesh current collector are shown in Fig. 1. The polymer has a single redox couple ${ }^{9}$ between 1.5 and $4.0 \mathrm{~V} v s . \mathrm{Li}^{+} / \mathrm{Li}$, with the onset of oxidation occurring at about $3.25 \mathrm{~V}$. The oxidation and reduction peaks are due to the intercalation and deintercalation of $\mathrm{PF}_{6}^{-}$by the polymer. Because of the strong dependence of electronic conductivity on state of charge, a well-defined reduction peak is obtained only from a thin, porous polymer film. The reversible capacity is about $28 \mathrm{mAh} / \mathrm{g}$ of

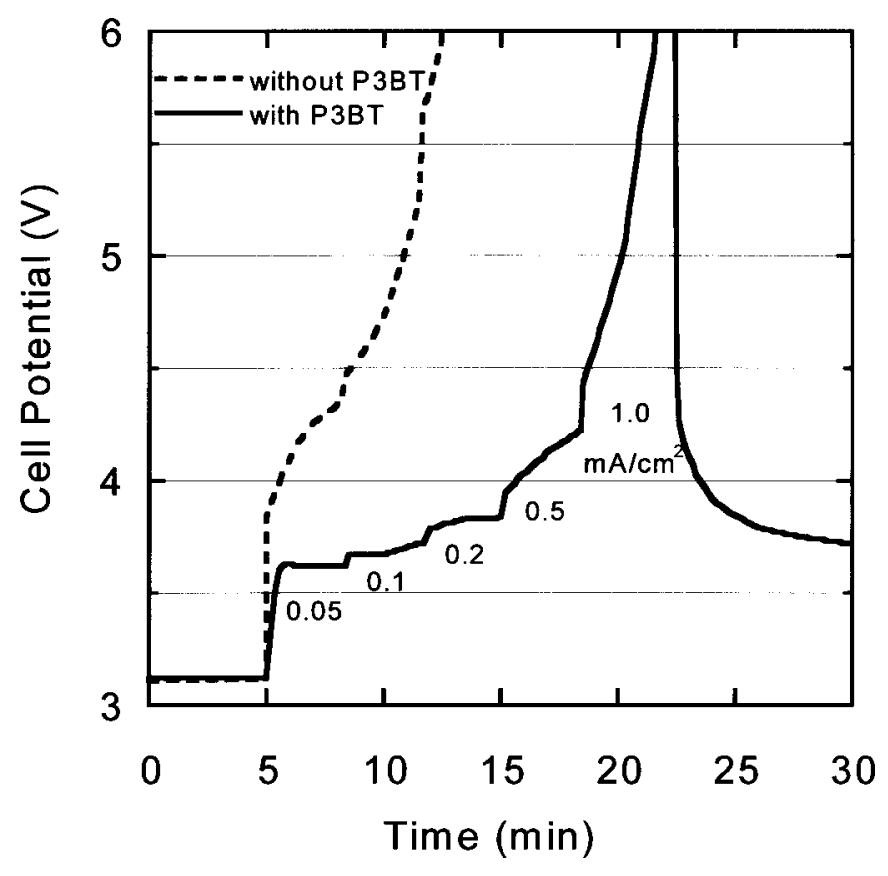

Figure 3. Potential at different current densities across separator with and without P3BT.

polymer. The commercial polypropylene lithium battery separator membrane used here (Fig. 2a) has a nonuniform porosity of $55 \%$. The polymer deposited from $\mathrm{CHCl}_{3} / \mathrm{DMF}$ solution formed a uniform deposit, producing a composite membrane (Fig. 2b) containing $0.4 \mathrm{mg}$ of P3BT with $47 \%$ porosity.

Figure 3 shows potential profiles at different current densities for cells containing untreated and P3BT-impregnated membranes sandwiched between stainless steel current collectors and Li foil electrodes. The P3BT cell was able to hold a constant potential by shorting through the conductive polymer for current densities up to $0.2 \mathrm{~mA} / \mathrm{cm}^{2}$. The relatively low maximum current density for this composite membrane compared with that measured in pure polymer films is attributed to the narrow current paths through the pores of the separator and/or an inhomogeneous distribution of the conducting polymer phase.

Application of P3BT impregnated separator in $\mathrm{TiS}_{2}$ Li cells.$\mathrm{TiS}_{2}$ was chosen as cathode material for its cycling stability below $3.5 \mathrm{~V} v s . \mathrm{Li}^{+} / \mathrm{Li}$ and because it is rapidly degraded by overcharging. With an upper limit of $3.5 \mathrm{~V}$ (Fig. 4), an unprotected cell cycled reversibly with a discharge capacity of $190 \mathrm{mAh} / \mathrm{g}$. On charging at $0.25 \mathrm{~mA} / \mathrm{cm}^{2}(\mathrm{C} / 10)$ to a limit of $4.0 \mathrm{~V}$ (Fig. 5), the capacity of the cell decreased rapidly on each overcharge cycle, and the cell failed to accept charge after eight cycles. Figure 6 shows the cycling behavior of a $\mathrm{TiS}_{2}$ - $\mathrm{Li}$ cell in the presence of the P3BT composite separator. This cell held a constant potential of $3.10 \mathrm{~V}$ at $0.06 \mathrm{~mA} / \mathrm{cm}^{2}(\mathrm{C} / 8)$, and did not reach the voltage limit $(4.0 \mathrm{~V})$ within the time limit of $12 \mathrm{~h}$. The discharge capacity of the protected cell was $150 \mathrm{mAh} / \mathrm{g}$, somewhat lower than that of the unprotected cell. This may be due to self-discharge during the relaxation of the polymer to its insulating state, and also to the somewhat greater internal resistance of the less porous separator. Self-discharge during normal cell operation was insignificant. These phenomena and their implications for cell design will be discussed in a future publication. The capacity of the protected cell was stable despite repeated longterm overcharging, demonstrating efficient reversible internal shorting through the electroactive polymer. Increasing the charging rate to $0.25 \mathrm{~mA} / \mathrm{cm}^{2}(\mathrm{C} / 2)$ increased the holding potential to about $3.2 \mathrm{~V}$. 


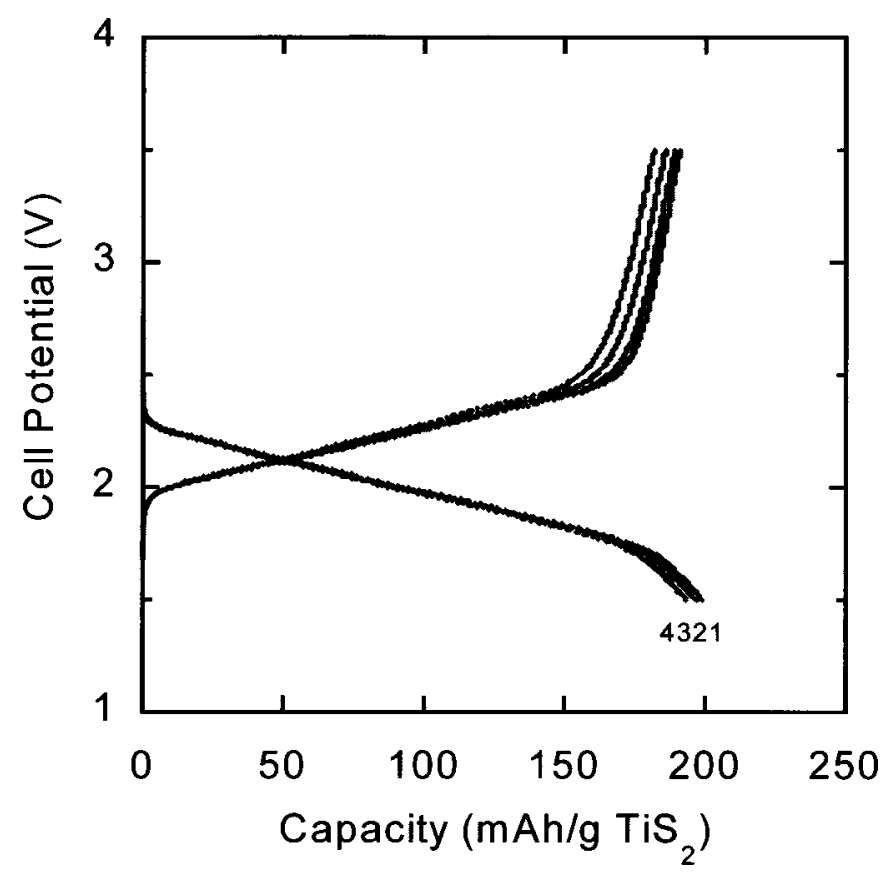

Figure 4. Charge-discharge cycling of $\mathrm{TiS}_{2}$ - $\mathrm{Li}$ cell: upper voltage limit 3.5 $\mathrm{V}, 0.25 \mathrm{~mA} / \mathrm{cm}^{2}$.

Above $0.5 \mathrm{~mA} / \mathrm{cm}^{2}$ overcharging, the cell potential increased rapidly, and overcharge protection could not be achieved through this composite membrane.

Because commercial cells require higher charging rates, the current carrying capability of the composite membranes must be improved. The current sustainable in a conductive polymer is strongly affected by the morphology of the polymer, which is in turn controlled by the details of sample preparation and processing as well as the nature of the substrate. For example, casting from different solvents clearly influences the performance of the polymer studied

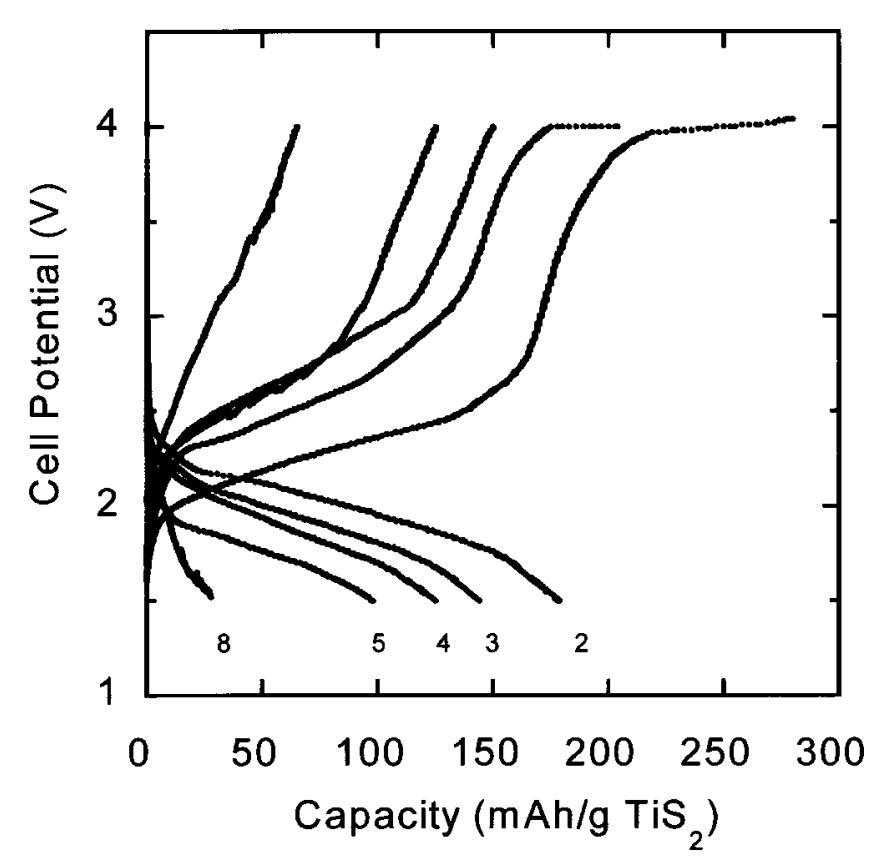

Figure 5. Overcharge cycling of $\mathrm{TiS}_{2}-\mathrm{Li}$ cell: upper voltage limit $4.0 \mathrm{~V}$, $0.25 \mathrm{~mA} / \mathrm{cm}^{2}$.

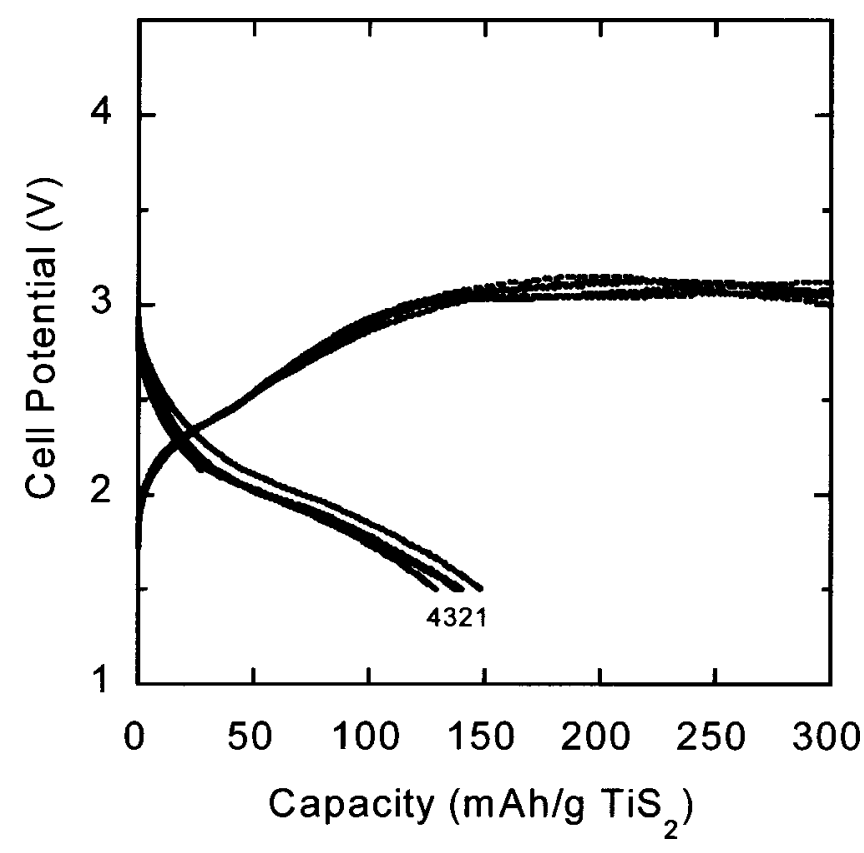

Figure 6. Overcharge cycling of $\mathrm{TiS}_{2}$ - Li cell with P3BT-impregnated separator: charged at $0.06 \mathrm{~mA} / \mathrm{cm}^{2}$ for $12 \mathrm{~h}$, discharged at $0.25 \mathrm{~mA} / \mathrm{cm}^{2}$; upper voltage limit: $4.0 \mathrm{~V}$.

here. The effects of other design factors such as the electroactive polymer oxidation potential, volume fraction, and distribution in the cell are under investigation.

Toward polymer shunt materials for $4 \mathrm{~V}$ cells.-The onset potentials and conductivities of electroactive polymers depend upon the nature of the polymer backbone, the type and location of substituents, the nature of the counter anion (dopant), and the degree of doping. Guerrero et al. ${ }^{10}$ found that the oxidation potentials of a series of poly(3-phenylthiophenes) substituted by electron-donating and withdrawing groups varied by as much as $1.6 \mathrm{~V}$, reaching a value of about $4.5 \mathrm{~V}$ vs. $\mathrm{Li}^{+} / \mathrm{Li}$ for a $-\mathrm{CF}_{3}$ substituted polymer. Therefore, it should be possible to find appropriate materials for protection of cells using $\mathrm{LiCoO}_{2}, \mathrm{LiNiO}_{2}$, and $\mathrm{LiMn}_{2} \mathrm{O}_{4}$ cathodes.

\section{Conclusion}

P3BT was impregnated into a microporous polypropylene separator though solution casting. The resulting composite membrane had a thin surface polymer layer, and the polymer filled about $10 \%$ of the membrane pores. On oxidation, the insulating membrane became electronically conducting. When incorporated in a $\mathrm{TiS}_{2}-\mathrm{Li}$ cell, membrane set an upper potential limit during overcharging, thereby protecting the cell from damage and preserving its discharge capacity. Future work will focus on polymers with higher oxidation onset potentials suitable for overcharge protection in $4 \mathrm{~V}$ lithium ion batteries.

\section{Acknowledgments}

The authors thank Dr. Eduardo Saiz of LBNL for assistance in SEM imaging. This work was supported by the Assistant Secretary for Energy Efficiency and Renewable Energy, Office of FreedomCAR and Vehicle Technologies of the U.S. Department of Energy under contract no. DE-AC03-76SF00098.

Lawrence Berkeley National Laboratory assisted in meeting the publication costs of this articles. 


\section{References}

1. S. R. Narayanan, S. Surampudi, A. I. Attia, and C. P. Bankston, J. Electrochem. Soc., 138, 2224 (1991).

2. M. N. Golovin, D. P. Wilkinson, J. T. Dudley, D. Holonko, and S. Woo, J. Electrochem. Soc., 139, 5 (1992).

3. T. J. Richardson and P. N. Ross, Jr., J. Electrochem. Soc., 143, 3992 (1996).

4. M. Adachi, K. Tanaka, and K. Sekai, J. Electrochem. Soc., 146, 1256 (1999); U.S. Pat. 5,763,119 (1998).

5. T. J. Richardson and P. N. Ross, Jr., in Lithium Batteries, R. A. Marsh, Z. Ogumi, J. Prakash, and S. Surampudi, Editors, PV 99-25, p. 687, The Electrochemical
Society Proceedings Series, Pennington, NJ (2000).

6. F. R. Denton, J. N. Howard, A. A. Anani, and J. M. Fernandez, U.S. Pat. 6,228,516 (Motorola) (2001).

7. R. Menon, C. O. Yoon, D. Moses, and A. J. Heeger, in Handbook of Conducting Polymers, 2nd ed., T. A. Skotheim, R. L. Elsenbaumer, and J. R. Reynolds, Editors, pp. 27-84, Marcel Dekker, Inc., New York (1998).

8. Y. Harima, T. Eguchi, and K. Yamashita, Synth. Met., 95, 69 (1998).

9. P. Novák, K. Müller, K. S. V. Santhanam, and O. Haas, Chem. Rev. (Washington, D.C.), 97, 207 (1997).

10. D. J. Guerrero, X. Ren, and J. P. Ferraris, Chem. Mater., 6, 1437 (1994). 